\title{
Article \\ Acute Cd Toxicity, Metal Accumulation, and Ion Loss in Southern Catfish (Silurus meridionalis Chen)
}

\author{
Wenming Liu *, Hanxun Qiu, Yulian Yan and Xiaojun Xie *
}

Key Laboratory of Freshwater Fish Reproduction and Development, Ministry of Education, School of Life Sciences, Southwest University, Chongqing 400715, China; qiuhx302315@email.swu.edu.cn (H.Q.); yanyul@swu.edu.cn (Y.Y.)

* Correspondence: lwm1981@swu.edu.cn (W.L.); xjxie@swu.edu.cn (X.X.); Tel.: +86-23-6825-3505 (W.L. \& X.X.)

Citation: Liu, W.; Qiu, H.; Yan, Y.; Xie, X. Acute Cd Toxicity, Metal Accumulation, and Ion Loss in Southern Catfish (Silurus meridionalis Chen). Toxics 2021, 9, 202. https:// doi.org/10.3390/toxics9090202

Academic Editors:

Markus Brinkmann and Maria Luisa Fernández-Cruz

Received: 17 June 2021

Accepted: 27 August 2021

Published: 29 August 2021

Publisher's Note: MDPI stays neutral with regard to jurisdictional claims in published maps and institutional affiliations.

Copyright: (c) 2021 by the authors. Licensee MDPI, Basel, Switzerland. This article is an open access article distributed under the terms and conditions of the Creative Commons Attribution (CC BY) license (https:/ / creativecommons.org/licenses/by/ $4.0 /)$.

\begin{abstract}
The amounts of cadmium in multiple organs and the amounts of $\mathrm{Na}^{+}$and $\mathrm{Ca}^{2+}$ in the carcass were measured in dead and surviving southern catfish exposed to different concentrations of Cd. The $96 \mathrm{~h}$ median lethal concentration was $6.85 \mathrm{mg} / \mathrm{L}$. The Cd content and Cd accumulation rate were positively correlated with $\mathrm{Cd}$ exposure concentrations, and there were significant differences between dead and surviving individuals, indicating that both $\mathrm{Cd}$ content in tissues and $\mathrm{Cd}$ accumulation rates were correlated with mortality. Cd levels in the liver of dead fish were saturated. A lethal threshold for $\mathrm{Cd}$ concentration in the whole fish was obtained. Bioconcentration factors for $\mathrm{Cd}$ did not decrease with increasing exposure. Acute exposure to waterborne $\mathrm{Cd}$ caused a significant decrease in the ion content of the fish carcass. There was a significant difference between the $\mathrm{Na}^{+}$ content of the carcass of dead fish $(34.54 \mu \mathrm{mol} / \mathrm{g}$ wet weight) and surviving fish $(59.34 \mu \mathrm{mol} / \mathrm{g}$ wet weight), which was not the case with the $\mathrm{Ca}^{2+}$ content, indicating that the lethal toxicity of Cd was probably related to the decrease in $\mathrm{Na}^{+}$content. Collectively, these results suggest that whole-fish $\mathrm{Cd}$ concentration and carcass $\mathrm{Na}^{+}$content can be useful indicators of fish acutely exposed to $\mathrm{Cd}$.
\end{abstract}

Keywords: cadmium; acute toxicity; accumulation; bioconcentration factor; calcium; sodium; Silurus meridionalis

\section{Introduction}

Anthropogenically derived impacts have unequivocally contributed to environmental poisoning by metals in aquatic ecosystems during the last few decades [1]. Among these heavy metals, cadmium (Cd) is of particular concern because of its widespread distribution in the aquatic environment [2,3], and because it is highly toxic to both fish and invertebrate marine organisms [4-7]. Heavy metals have a bioaccumulative nature. Bioaccumulation means the accumulation over time of a substance, especially a contaminant (such as a heavy metal), in a living organism [8]. Cd tends to accumulate in fish and invertebrate marine organisms [7]; as fish and invertebrate marine organisms represent the main contaminated foods that are consumed by humans, $\mathrm{Cd}$ is indirectly becoming toxic to human beings [7]. In China, the Cd concentration in normal fresh water ranges from $10 \mathrm{ng} / \mathrm{L}$ to $8 \mu \mathrm{g} / \mathrm{L}$ [9]; $\mathrm{Cd}$ and $\mathrm{Cd}$ concentrations in polluted water range from 0.8 to $12.05 \mathrm{mg} / \mathrm{L}[9,10]$. $\mathrm{Cd}$ pollution incidents are frequently found in aquatic systems in China such as that in the Guangdong North River in Shaoguan city in 2005 and the Longjiang Cd pollution event in Hechi, Guangxi in 2012 [11]. Cd emissions have occurred occasionally, so cadmium exposure is a real danger to aquatic organisms, including fish [12,13]. Cd pollution will have a negative impact on the fitness and survival of aquatic organisms, as indicated by a decrease in biodiversity of polluted areas [10]. Cd accumulation in fish can cause a variety of toxicities, including ion regulation disorders, oxidative damage, endocrine disorders, genetic toxicity, histopathological changes, and can even result in the death of fish [14-19].

The acute or chronic intoxication of organisms and a variety of adverse effects from $\mathrm{Cd}$ have emerged as a global environmental threat to aquatic organisms and aquatic ecosys- 
tems. Toxicity to fish resulting from acute exposure to $\mathrm{Cd}$ in water has been extensively studied $[15,20,21]$. These studies have mostly reported $96 \mathrm{~h}$ median lethal concentrations, indicating the sensitivity of different fish species to $\mathrm{Cd}$ exposure in water. However, even under controlled conditions, the $\mathrm{LC}_{50}$ (median lethal concentration) can be affected by external physical, chemical, and biological factors in the aquatic environment [22,23]. A query in the EPA ECOTOX database [24] for $96 \mathrm{~h} \mathrm{LC}_{50}$ (a $96 \mathrm{~h}$ median lethal concentration) values of $\mathrm{Cd}$ toxicity for zebrafish (Danio rerio) in recent literature found a wide range of concentrations: $96 \mathrm{~h} \mathrm{LC}_{50}$ for Cd was between 3822 and 22,482 $\mu \mathrm{g} / \mathrm{L}[14,25,26]$. The concentration of accumulated heavy metals in target sites of fish organs and tissues is closer to the actual concentration of heavy metal toxicity and is not easily affected by external factors. Therefore, the tissue residue approach (TRA) was proposed [27], which uses tissue concentration as a more reliable toxicity indicator, and its application in environmental toxicology studies is of great value for the protection of species and the ecological environment [28-31]. Current studies on the toxicity of $\mathrm{Cd}$ according to TRA have mainly focused on aquatic oligochaetes [22,32,33], and there is a lack of studies in fish [34]. Although studies have compared the difference between whole-fish $\mathrm{Cd}$ content in dead and surviving fish under acute waterborne $\mathrm{Cd}$ exposure $[35,36]$, they did not consider looking at the difference in whole fish $\mathrm{Cd}$ content under different $\mathrm{Cd}$ exposure concentrations, nor studying different tissues to determine if there were differences in $\mathrm{Cd}$ content, nor elucidating the quantitative relationship between $\mathrm{Cd}$ exposure concentrations and tissue $\mathrm{Cd}$ content. Therefore, it is necessary to study the relationship between $\mathrm{Cd}$ content and toxicity in different organs and tissues of fish under acute $\mathrm{Cd}$ exposure conditions in the water.

Following $\mathrm{Cd}$ exposure, the main mechanism of fish toxicity is the disturbance of $\mathrm{Na}^{+}$and $\mathrm{Ca}^{2+}$ ion homeostasis [14,36-43]. Whole body $\mathrm{Na}^{+}$levels in zebrafish (Danio rerio) and rainbow trout (Oncorhynchus mykiss) are commonly used as indicators for acute and subacute $\mathrm{Cd}^{2+}$ toxicity in fish $[14,15,36]$. Most studies on the effect of $\mathrm{Cd}^{2+}$ on fish $\mathrm{Ca}^{2+}$ levels have focused on blood $[37,44]$, and the toxic effects of $\mathrm{Cd}^{2+}$ have only been occasionally studied using the whole body $\mathrm{Ca}^{2+}$ level in fish $[4,45]$. It is not clear whether the principles of $\mathrm{Cd}$ toxicity established by these model organisms also apply to other non-model fish [46].

The southern catfish (Silurus meridionalis Chen) is a carnivorous fish with a rapid growth rate and high economic value, and it is widely distributed in the Yangtze River and southern regions of China [47] (Figure A1). Southern catfish is commonly consumed as a potentially valuable protein source [48]. Due to the influence of water pollution and other factors, the southern catfish has lost its dominant position in some sections of the Yangtze River [49]. Studies have shown that the southern catfish readily takes up Cd from the aquatic environment, leading to high $\mathrm{Cd}$ content in the body although information regarding $\mathrm{Cd}$ toxicity in this species is limited. Carnivorous fish have a strong ability to biomagnify $\mathrm{Cd}$ in the food chain [50]. The chronic exposure of southern catfish to $\mathrm{Cd}$ damages liver mitochondrial structure and function [51], causes oxidative damage to the gills, liver, and kidney tissues [52], and also affects growth and development [53]. However, gaps remain in the knowledge regarding acute exposure and tissue-specific $\mathrm{Cd}$ accumulation. In order to protect this economically important food fish, it is necessary to determine the tolerance limit of southern catfish to $\mathrm{Cd}$ as a persistent heavy metal pollutant. Acute toxicity testing plays an important role in the sustainable management and conservation of the natural habitats of fish [50]. In addition, fish can take up Cd from both waterborne and dietary sources; foodborne exposure generally leads to higher metal concentrations in the intestines compared with the gills, whereas for waterborne exposure, metal concentrations in the kidneys and the gills are the higher than in the other tissues [54]. Therefore, this study aimed to consider the following acute waterborne Cd exposure conditions for southern catfish: (1) the quantitative relationships between $\mathrm{Cd}$ accumulation concentration in different organs and tissues and $\mathrm{Cd}$ exposure concentration, (2) the different accumulated $\mathrm{Cd}$ concentrations between living and dead fish, and (3) the relationships between $\mathrm{Na}^{+}$and $\mathrm{Ca}^{2+}$ content and acute $\mathrm{Cd}$-induced death. 


\section{Materials and Methods}

\subsection{Experimental Water and Reagents}

Deionized water $(5 \mu \mathrm{s} / \mathrm{cm}$ ) was obtained using a water purifier (LD 3000G A2, Chongqing Lidi Experiment Instrument Co., Ltd., Chongqing, China). $\mathrm{MgSO}_{4} \cdot 7 \mathrm{H}_{2} \mathrm{O}$ (AR), $\mathrm{KCl}(\mathrm{AR}), \mathrm{CaCl}_{2} \cdot 2 \mathrm{H}_{2} \mathrm{O}(\mathrm{AR}), \mathrm{NaHCO}_{3}(\mathrm{AR})$, and $\mathrm{CdCl}_{2}$ (99.995\% purity on trace metal basis) were purchased from Solarbio Life Sciences. Nitric acid $\left(\mathrm{HNO}_{3}\right.$, certified reagent grade) was purchased from Chongqing Chuandong Chemical Industry Group Co. LTD (Chongqing, China). Perchloric acid $\left(\mathrm{HClO}_{4}\right.$, certified reagent grade) was purchased from Chengdu Kelong Chemical Co. LTD (Chengdu, China). All glassware and polyethylene vials were kept in $10 \% \mathrm{HNO}_{3}$ solution overnight and rinsed three times with ultrapure water prior to use.

\subsection{Experimental Fish and Acclimation}

All animal procedures were conducted in accordance with the Institutional Animal Care and Use Committee (IACUC) guidelines of Southwest University (IACUC-2018030301 ) and the environment and housing facilities for laboratory animals of China (GB/T 14925-2001). Juvenile southern catfish were acquired from the Institute of Hydrobiology and Water Environments, Southwest University, Chongqing, China. The fish weighed nearly $40 \mathrm{~g}$ and were acclimated in a polyethylene recirculating rearing system for 2 weeks, under a photoperiod with $12 \mathrm{~h}$ of light and $12 \mathrm{~h}$ of dark (12 L:12 D), before the start of the experiment. During the acclimation period, the fish were fed to satiation with fresh pieces of grass carp (Ctenopharyngodon idella) once daily at 18:00. About $50 \%$ of the water in the recirculating rearing system was renewed daily. The water quality parameters were as follows: temperature $27.5 \pm 0.1^{\circ} \mathrm{C}, \mathrm{pH} 7.10 \pm 0.2$, dissolved oxygen above $7.5 \mathrm{mg} / \mathrm{L}$, ammonia concentration under $0.03 \mathrm{mg} / \mathrm{L}$, and $\mathrm{CaCO}_{3}$ hardness of $25.2 \pm 0.2 \mathrm{mg} / \mathrm{L}$ (OECD 203 annex 2, 1992: $\mathrm{MgSO}_{4} \cdot 7 \mathrm{H}_{2} \mathrm{O} 0.0123 \mathrm{~g} / \mathrm{L}, \mathrm{KCl} 0.0006 \mathrm{~g} / \mathrm{L}, \mathrm{CaCl}_{2} \cdot 2 \mathrm{H}_{2} \mathrm{O} 0.0294 \mathrm{~g} / \mathrm{L}$, and $\mathrm{NaHCO}_{3} 0.0065 \mathrm{~g} / \mathrm{L}$ ). The study was conducted in accordance with the ethical requirements and recommendations for animal care of the Fisheries Science Institution of Southwest University, China.

\subsection{Acute Cd Exposure}

The experiment was conducted based on guidelines provided by Vergauwen (2013) [25] and Yilmaz (2004) [55]. After two weeks of acclimation, two hundred healthy and similarsized fish $(50.0 \pm 0.2 \mathrm{~g})$ were randomly distributed to thirteen $400 \mathrm{~L}$ polyethylene recirculating rearing systems. Each system consisted of 20 breeding units (length $\times$ width $\times$ height $=39 \mathrm{~cm} \times 27 \mathrm{~cm} \times 25 \mathrm{~cm}$ ). Ten or twenty fish were kept within each recirculating rearing system. However, in order to avoid cannibalism, each fish was kept in a separate breeding unit. The nominal total $\mathrm{Cd}$ concentrations were 0 (control), 3, 4, 5, 6, 7, 8, 9, 10, 11, 12, 13, and $14 \mathrm{mg} / \mathrm{L}$ for each exposure system. $\mathrm{Cd}$ was added as $\mathrm{CdCl}_{2}$ (Beijing Solarbio Science and Technology Co., Ltd., Beijing, China). It was dissolved in distilled water to obtain stock solutions of $20 \mathrm{mg} / \mathrm{mL} \mathrm{Cd}^{2+}$. Desired $\mathrm{Cd}^{2+}$ levels were achieved by adding appropriate volumes of the stock solution to the aquarium water. During the test period, the water was renewed (50\%) each morning, and the corresponding stock solution of $\mathrm{Cd}^{2+}$ was added at the time of the water change. Total $\mathrm{Cd}$ concentrations were measured with flame atomic absorption spectrometry (TAS 990, Beijing Purkinje General Instrument Corporation, Beijing, China) and adjusted before the start of the experiment and every $12 \mathrm{~h}$ during the experiment to ensure a maximum $10 \%$ deviation from the nominal concentrations. The actual measured dissolved $\mathrm{Cd}^{2+}$ concentrations (after $0.45 \mu \mathrm{m}$ filtration) were $0,2.96 \pm$ $0.13,3.97 \pm 0.18,5.01 \pm 0.11,5.98 \pm 0.23,7.02 \pm 0.05,8.02 \pm 0.06,8.97 \pm 0.06,10.01 \pm 0.06$, $11.03 \pm 0.10,11.98 \pm 0.06,13.01 \pm 0.02$, and $14.02 \pm 0.05 \mathrm{mg} / \mathrm{L}(\mathrm{n}=8)$, respectively. The fish were starved two days prior to the experiment and did not feed throughout the acute toxicity trials. During the test period, the temperature, $\mathrm{pH}$, dissolved oxygen concentration, ammonia-nitrogen concentration, water hardness, and photoperiod were identical to those used during acclimation. In order to minimize the effects of continued immersion in tanks 
on the amounts of $\mathrm{Cd}^{2+}, \mathrm{Ca}^{2+}$, and $\mathrm{Na}^{+}$in dead fish, the fish were taken within $1 \mathrm{~h}$ after death. Mortality and time to death were recorded every $1 \mathrm{~h}$ over $96 \mathrm{~h}$, and dead fish were immediately removed, rinsed in Cd-free reconstituted water, then sampled. After $96 \mathrm{~h}$, fish that survived the toxicity test were rinsed in Cd-free reconstituted water, then sampled. The gills, liver, kidneys, and heart were removed, weighed, and saved, as was the remaining carcass. The gills were vigorously rinsed in deionized water and blotted dry immediately after removal. All samples were stored at $-80{ }^{\circ} \mathrm{C}$ until their use for the determination of the tissue $\mathrm{Cd}$ concentration and ion $(\mathrm{Ca}, \mathrm{Na})$ analysis.

\subsection{Tissue $\mathrm{Cd}$ and $\mathrm{Ion}\left(\mathrm{Na}^{+}\right.$and $\left.\mathrm{Ca}^{2+}\right)$ Analysis}

After weighing, the tissue samples were digested with $\mathrm{HNO}_{3}$ and $\mathrm{HClO}_{4}$. The carcasses were dried at $70{ }^{\circ} \mathrm{C}$ to a constant weight and then ground to a fine powder with a mortar and pestle. A total of $300 \mathrm{mg}$ of the powder was digested in $\mathrm{HNO}_{3}$ and $\mathrm{HClO}_{4}$. The digestion process was initiated at room temperature overnight, followed by incubation in a hot block (EH35A Plus, LabTech, Beijing, China) at $120^{\circ} \mathrm{C}$. The resulting solution was evaporated, and the residue was redissolved in $0.5 \% \mathrm{HNO}_{3}$.

The $\mathrm{Cd}^{2+}$ and $\mathrm{Ca}^{2+}$ content of all samples was measured by flame atomic absorption spectrometry (FAAS) (TAS-990, Beijing Purkinje General Instrument Corporation, Beijing, China), and the $\mathrm{Na}^{+}$content of the carcasses were measured by flame photometry (AP1500, Aopu Analytical Instruments, Shanghai, China). The quality was assessed for each batch of digested samples, and each batch included blank samples and trace element-spiked samples. The calculated recoveries of the reference material were $98.70 \%, 96.51 \%$, and $100.04 \%$ for $\mathrm{Na}, \mathrm{Ca}$, and $\mathrm{Cd}$, respectively.

\subsection{Calculations and Statistical Analysis}

The Cd content was expressed as $\mu \mathrm{g} / \mathrm{g}$ wet weight and calculated using measured concentrations and tissue weights, with whole body values representing the sum of measured tissue and carcass contents. Based on data for tissue $\mathrm{Cd}$ concentrations, we estimated the average accumulation rates of tissue Cd using the following equation [36]:

$$
\text { Accumulation rates of tissue } \mathrm{Cd}=(\text { Tissue } \mathrm{Cd}) / \mathrm{t}
$$

where $($ Tissue $\mathrm{Cd})=\mathrm{Cd}$ concentration in the tissue of the southern catfish $(\mu \mathrm{g} \mathrm{Cd} / \mathrm{g}$ wet weight) collected at the time of death (hour) and the end of the experiment after $96 \mathrm{~h}$; and $\mathrm{t}$ is the fish collection time (hour).

The bioconcentration factor (BCF) for tissues were calculated considering the concentrations of $\mathrm{Cd}$ determined in the fish tissue $\left(\mathrm{C}_{f}, \mu \mathrm{g} / \mathrm{g}\right.$ wet weight $)$ and in the water in which the fish was raised $\left(C_{w}, \mu g / m L\right)$, using the equation [56]:

$$
\mathrm{BCF}=\mathrm{C}_{f} / \mathrm{C}_{\mathrm{w}}
$$

Data are presented as means \pm SEM. For the exposure concentration-response curves, the percentage of mortality after $96 \mathrm{~h}$ was presented as a function of the Cd exposure concentration. Normality of data was verified using the Shapiro-Wilk test, and the homogeneity of variances was tested using Levene's test. $\mathrm{Na}^{+}$and $\mathrm{Ca}^{2+}$ content was compared to the corresponding control value using Student's $t$-test. Analysis of covariance (ANCOVA: with $\mathrm{Cd}$ concentration in fish tissues as a dependent variable, $\mathrm{Cd}$ exposure concentration as a covariate, and outcome (dead or alive) as a response variable) was used to test for differences in overall $\mathrm{Cd}$ accumulation between dead and surviving fish. The analysis of covariance was also used to compare the rates of $\mathrm{Cd}$ accumulation. All statistical tests and linear regression estimations, and estimates of 95\% CI, were run using GraphPad PRISM 8.0 (GraphPad Software Inc., La Jolla, CA, USA) or IBM SPSS 22.0 (@ SPSS Inc., Chicago, IL, USA) at $p<0.05$. The logistic regression and analysis of covariance were used by IBM SPSS 22.0 (@ SPSS Inc., Chicago, IL, USA). Linear regression estimations and graphs were drawn with GraphPad PRISM 8.0 (GraphPad Software Inc., La Jolla, CA, USA). 


\section{Results}

\subsection{Mortality and $96 \mathrm{~h} L C_{50}$}

The mortality of southern catfish for each Cd exposure are presented in Figure 1. A clear, dose-dependent mortality was induced by $\mathrm{Cd}$ exposure test, where higher concentrations caused $100 \%$ mortality for all the fish, whereas the tanks spiked with lower doses of $\mathrm{Cd}$ were characterized by intermediate to zero mortality. No mortality occurred in the control $(0 \mathrm{mg} \mathrm{Cd} / \mathrm{L})$. Mortality is plotted as a function of the nominal concentration of $\mathrm{Cd}$ $(\mathrm{mg} / \mathrm{L})$. The relationship between mortality and $\mathrm{Cd}$ exposure concentrations can be fitted by a logistic regression equation (Figure 1$)$, and the regression model equation obtained was $y=1 /\left(0.01+75,918.77 \mathrm{e}^{-2.313 x}\right),\left(\mathrm{r}^{2}=0.850, p<0.05\right)(y=$ mortality, $x=\mathrm{Cd}$ exposure concentrations, $\mathrm{mg} / \mathrm{L}$ ). Based on this equation, the $96 \mathrm{~h} \mathrm{LC} 50$ value was $6.85 \mathrm{mg} / \mathrm{L}$.

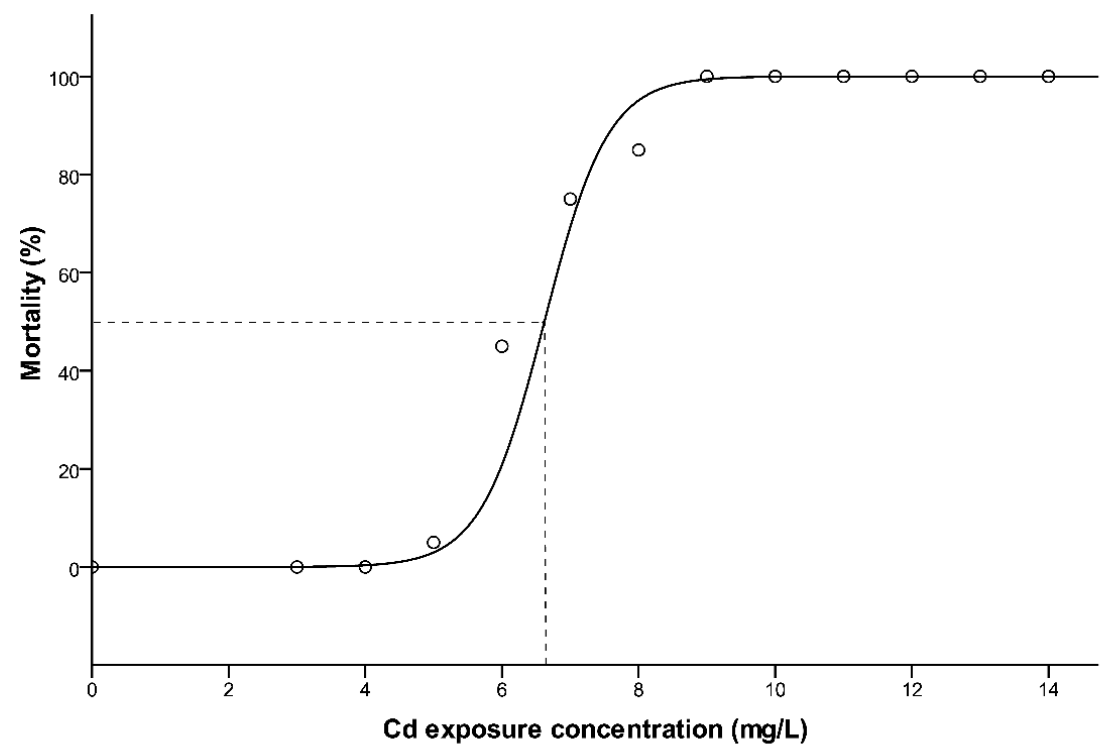

Figure 1. The logistic fit of the model to the dataset of $\mathrm{Cd}$ exposure for $96 \mathrm{~h}$. $\mathrm{LC}_{50}$ with dotted line in the graph.

\subsection{Cd Accumulation and Accumulation Rate Analysis of Tissues}

The relationship between $\mathrm{Cd}$ concentrations in different tissues and $\mathrm{Cd}$ exposure concentration is shown in Figure 2. There was a positive linear correlation between the $\mathrm{Cd}$ concentrations in the gills, kidneys, heart, and carcass of dead fish and the $\mathrm{Cd}$ exposure concentration of the whole fish $(p<0.05)$. However, there was no linear correlation between liver $\mathrm{Cd}$ accumulation and $\mathrm{Cd}$ exposure concentration $(p>0.05)$. The $\mathrm{Cd}$ concentrations in all tissues and in surviving whole fish were positively and linearly correlated with $\mathrm{Cd}$ exposure concentration $(p<0.05)$. Regression analyses for the six tissues examined from the 102 fish that died during the $96 \mathrm{~h}$ exposure are $y=4.07 x-$ 13.7, $\mathrm{r}^{2}=0.96, p<0.0001$ (gill); $y=0.823 x+10.9, \mathrm{r}^{2}=0.38, p>0.05$ (liver) $y=6.29 x+2.72$, $\mathrm{r}^{2}=0.94, p<0.0001$ (kidney); $y=0.867 x-3.50, \mathrm{r}^{2}=0.82, p<0.001$ (heart) $y=0.245 x-$ $0.402, \mathrm{r}^{2}=0.99, p<0.0001$ (carcass); $y=0.302 x-0.276, \mathrm{r}^{2}=0.99, p<0.0001$ (whole fish). Regression analyses for the six tissues examined from the 78 fish that survived the $96 \mathrm{~h}$ exposure are $y=1.02 x+0.764, \mathrm{r}^{2}=0.95, p<0.05$ (gill); $y=4.73 x-10.8, \mathrm{r}^{2}=0.69, p<0.05$ (liver); $y=4.33 x-3.10, \mathrm{r}^{2}=0.95, p<0.05$ (kidney); $y=0.347 x-1.01, \mathrm{r}^{2}=0.74, p<0.05$ (heart); $y=0.117 x-0.138, \mathrm{r}^{2}=0.91, p<0.001$ (carcass); $y=0.168 x-0.178, \mathrm{r}^{2}=0.95, p<0.001$ (whole fish), where $x$ is the $\mathrm{Cd}$ exposure concentration and $y$ is the $\mathrm{Cd}$ concentration for the respective tissues. 

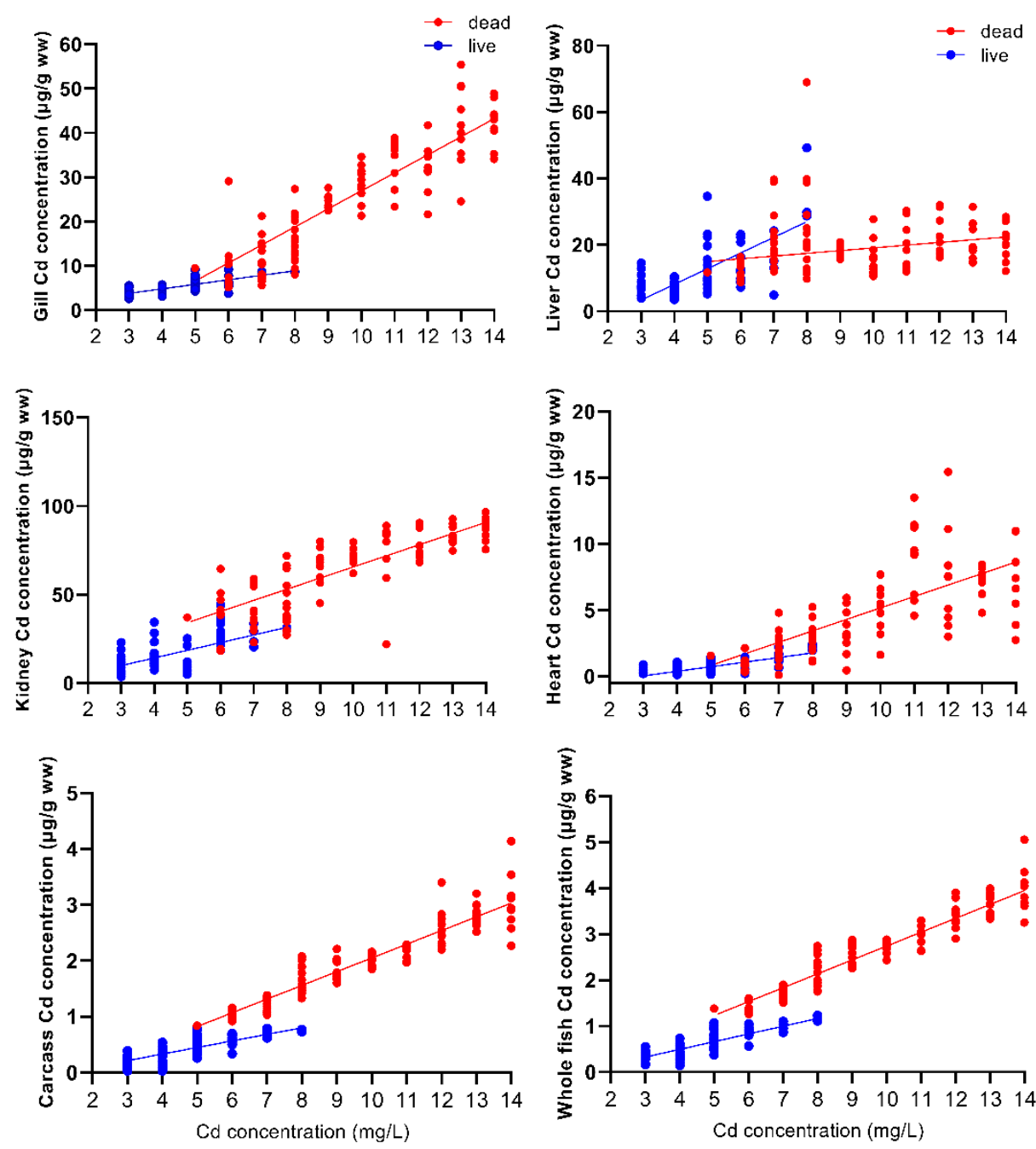

Figure 2. Relationship between the exposure and Cd accumulation concentrations in the gills, liver, kidneys, heart, carcass, and whole fish of Silurus meridionalis. Red dots represent fish that died within $96 \mathrm{~h}$, and blue dots represent fish that survived after the $96 \mathrm{~h}$ exposure. Regression analyses for the six tissues examined from the 102 fish that died during the $96 \mathrm{~h}$ exposure are indicated by the red line. Regression analyses for the six tissues examined from the 78 fish that survived the $96 \mathrm{~h}$ exposure are indicated by the blue line.

The slope of the accumulation of $\mathrm{Cd}$ concentrations in the gills, kidneys, heart, carcass, and whole body of dead fish with $\mathrm{Cd}$ exposure concentrations was significantly higher than that for the surviving fish (gill $F=68.336, p<0.001$; kidney $F=6.891, p<0.05$; heart $F=20.384, p<0.001$; carcass $F=35.260, p<0.001$; whole fish $F=44.615, p<0.001$ ). The effect of $\mathrm{Cd}$ exposure concentration on the $\mathrm{Cd}$ concentration in different tissues and the whole body of dead and surviving fish was also very significant (gill $F=179.149, p<0.001$; liver $F=32.485, p<0.001$; kidney $F=123.614, p<0.05$; heart $F=53.761, p<0.001$; carcass $F=371.862, p<0.001$; whole fish $F=545.561, p<0.001$ ). There was a clear threshold between the $\mathrm{Cd}$ concentration in the dead and surviving fish; in the surviving fish, the accumulation of $\mathrm{Cd}$ never exceeded $1.16 \mu \mathrm{g} / \mathrm{g}$ relative to the wet weight of whole fish, but in fish that died of acute $\mathrm{Cd}$ poisoning, the accumulation of $\mathrm{Cd}$ was a minimum of $1.38 \mu \mathrm{g} / \mathrm{g}$ wet weight of the whole fish (Figure 2).

$\mathrm{Cd}$ bioconcentration factors (BCF) in gill, liver, and kidney tissue were above 1, but in the heart, carcass, and the whole fish, BCF were below 1 (Figure A2). BCF in gill, heart, carcass, and the whole body of dead fish trended towards a positive relationship with exposure $(p<0.05)$, but liver tissue BCF trended towards an inverse relationship with exposure $(p<0.05)$. There were no linear correlations between the BCF in gill, liver, kidney, 
and heart tissues of surviving fish and $\mathrm{Cd}$ exposure concentration $(p>0.05)$. However, $\mathrm{BCF}$ in the carcass and whole body of surviving and dead fish trended towards a positive relationship with exposure $(p<0.05)$.

The relationship between the accumulation rate of $\mathrm{Cd}$ in different tissues and the $\mathrm{Cd}$ exposure concentration is shown in Figure 3. The $\mathrm{Cd}$ accumulation rates in the gills, liver, kidneys, heart, carcass, and the whole body of dead and surviving fish were linearly and positively correlated with the Cd exposure concentrations $(p<0.05)$. Regression analyses for the six tissues examined from the 102 fish that died during the $96 \mathrm{~h}$ exposure are $y=0.31 x-1.8, \mathrm{r}^{2}=0.89, p<0.001$ (gill); $y=0.14 x-0.58, \mathrm{r}^{2}=0.91, p<0.001$ (liver); $y=0.60 x-3.1, \mathrm{r}^{2}=0.91, p<0.001$ (kidney); $y=0.060 x-0.35, \mathrm{r}^{2}=0.92, p<0.001$ (heart); $y=0.021 x-0.12, \mathrm{r}^{2}=0.90, p<0.001$ (carcass); $y=0.027 x-0.15, \mathrm{r}^{2}=0.90, p<0.001$ (whole fish). Regression analyses for the six tissues examined from the 78 fish that survived the 96 h exposure are $y=0.011 x+0.0081, \mathrm{r}^{2}=0.95, p<0.001$ (gill) $; y=0.049 x-0.11, \mathrm{r}^{2}=0.69$, $p<0.05$ (liver); $y=0.046 x-0.035, \mathrm{r}^{2}=0.74, p<0.05$ (kidney); $y=0.0036 x-0.010, \mathrm{r}^{2}=0.74$, $p<0.05$ (heart); $y=0.0012 x-0.0015, \mathrm{r}^{2}=0.91, p<0.05$ (carcass); $y=0.0018 x-0.0019$, $\mathrm{r}^{2}=0.95, p<0.05$ (whole fish), where $x$ is the Cd exposure concentration and $y$ is the $\mathrm{Cd}$ accumulation rate for the respective tissues.

The slope of the $\mathrm{Cd}$ accumulation rate in different tissues and the whole body of dead fish with the $\mathrm{Cd}$ exposure concentration was significantly higher than that for the surviving fish (gill $F=149.001, p<0.001$; liver $F=33.025, p<0.001$; kidney $F=169.770, p<0.001$; heart $F=71.909, p<0.001$; carcass $F=143.405, p<0.001$; whole fish $F=175.555, p<0.001$ ). The effect of $\mathrm{Cd}$ exposure concentration on the accumulation rate of $\mathrm{Cd}$ in different tissues and the whole body of dead and surviving fish was also very significant (gill $F=168.796$, $p<0.001$; liver $F=90.655, p<0.001$; kidney $F=219.104, p<0.05$; heart $F=82.345, p<0.001$; carcass $F=199.249, p<0.001$; whole fish $F=219.440, p<0.001$ ).

\subsection{Carcass $\mathrm{Na}^{+}$and $\mathrm{Ca}^{2+}$ Status}

The concentrations of $\mathrm{Na}^{+}$ions in the control $(0 \mathrm{mg} \mathrm{Cd} / \mathrm{L})$ and the carcasses of dead and surviving fish after acute $\mathrm{Cd}$ exposure are shown in Figure 4 . After $\mathrm{Cd}$ exposure, the concentration of $\mathrm{Na}^{+}$ions in the surviving fish decreased by $23-44 \%$, while the concentration in the dead fish decreased by $51-68 \%$, as compared with the concentration of $\mathrm{Na}^{+}$ions in the carcasses of the controls $(0 \mathrm{mg} \mathrm{Cd} / \mathrm{L})$. When the $\mathrm{Cd}$ exposure concentration was $96 \mathrm{~h} \mathrm{LC}_{50}$, the $\mathrm{Na}^{+}$ion concentration suddenly decreased to $61 \%$ (Figure $4 \mathrm{~A}$ ). Although the concentration of $\mathrm{Na}^{+}$ions $(59.34 \pm 1.29 \mu \mathrm{mol} / \mathrm{g}$ wet weight) of all the surviving fish after $\mathrm{Cd}$ exposure was significantly higher than that of all the dead fish $(34.54 \pm 0.56 \mu \mathrm{mol} / \mathrm{g}$ wet weight) $\left(p<0.001, t\right.$-test), the concentration of $\mathrm{Na}^{+}$ions was significantly lower than that of the control $(0 \mathrm{mg} \mathrm{Cd} / \mathrm{L})(92.24 \pm 2.51 \mu \mathrm{mol} / \mathrm{g}$ wet weight) $(p<0.001, t$-test) (Figure $4 \mathrm{~B})$.

The concentrations of $\mathrm{Ca}^{2+}$ ions in the control $(0 \mathrm{mg} \mathrm{Cd} / \mathrm{L})$ and the carcasses of dead and surviving fish after acute $\mathrm{Cd}$ exposure are shown in Figure 5. There was no clear boundary between the concentration of $\mathrm{Ca}^{2+}$ ions in the dead and surviving fish after $\mathrm{Cd}$ exposure (Figure 5A). Comparison of the overall mean $\mathrm{Ca}^{2+}$ concentration of the carcass showed that the $\mathrm{Ca}^{2+}$ concentration $(160.67 \pm 3.89 \mu \mathrm{mol} / \mathrm{g}$ wet weight) of all the dead fish after $\mathrm{Cd}$ exposure was significantly higher than that of all the surviving fish $(145.01 \pm 5.99 \mu \mathrm{mol} / \mathrm{g}$ wet weight) $(p=0.030, t$-test), but significantly lower than the carcass $\mathrm{Ca}^{2+}$ concentration of all controls $(0 \mathrm{mg} \mathrm{Cd} / \mathrm{L})(444.08 \pm 18.43 \mu \mathrm{mol} / \mathrm{g}$ wet weight $)$ $(p=0.000, t$-test) (Figure 5B). 

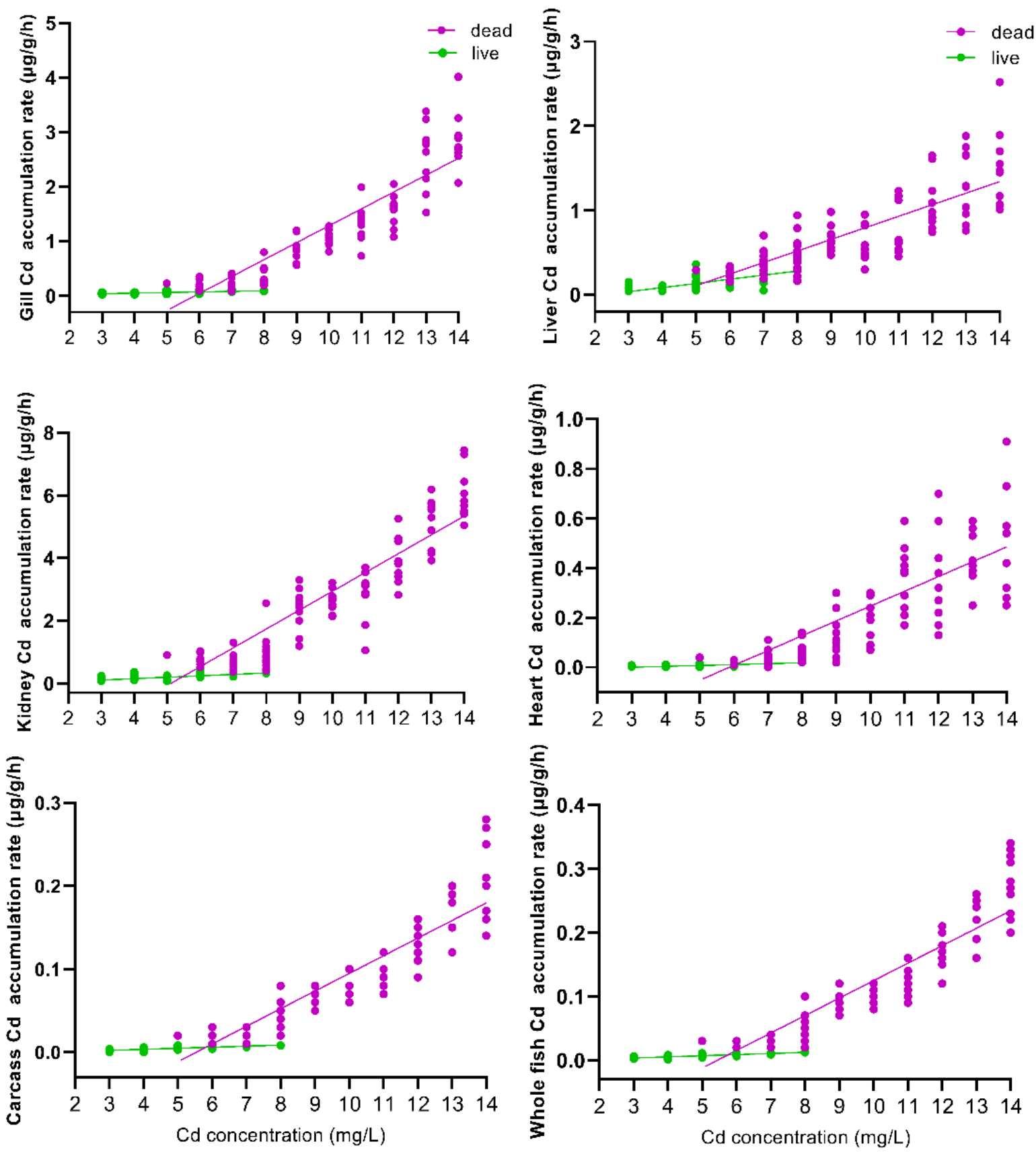

Figure 3. Relationship between exposure concentration and the $\mathrm{Cd}$ accumulation rate in the gills, liver, kidneys, heart, carcass, and whole fish of Silurus meridionalis. Purple dots represent fish that died within $96 \mathrm{~h}$, and green dots represent fish that survived the $96 \mathrm{~h}$ exposure. Regression analyses for the six tissues examined from the 102 fish that died during the $96 \mathrm{~h}$ exposure are indicated by the purple line. Regression analyses for the six tissues examined from the 78 fish that survived the $96 \mathrm{~h}$ exposure are indicated by the green line. 

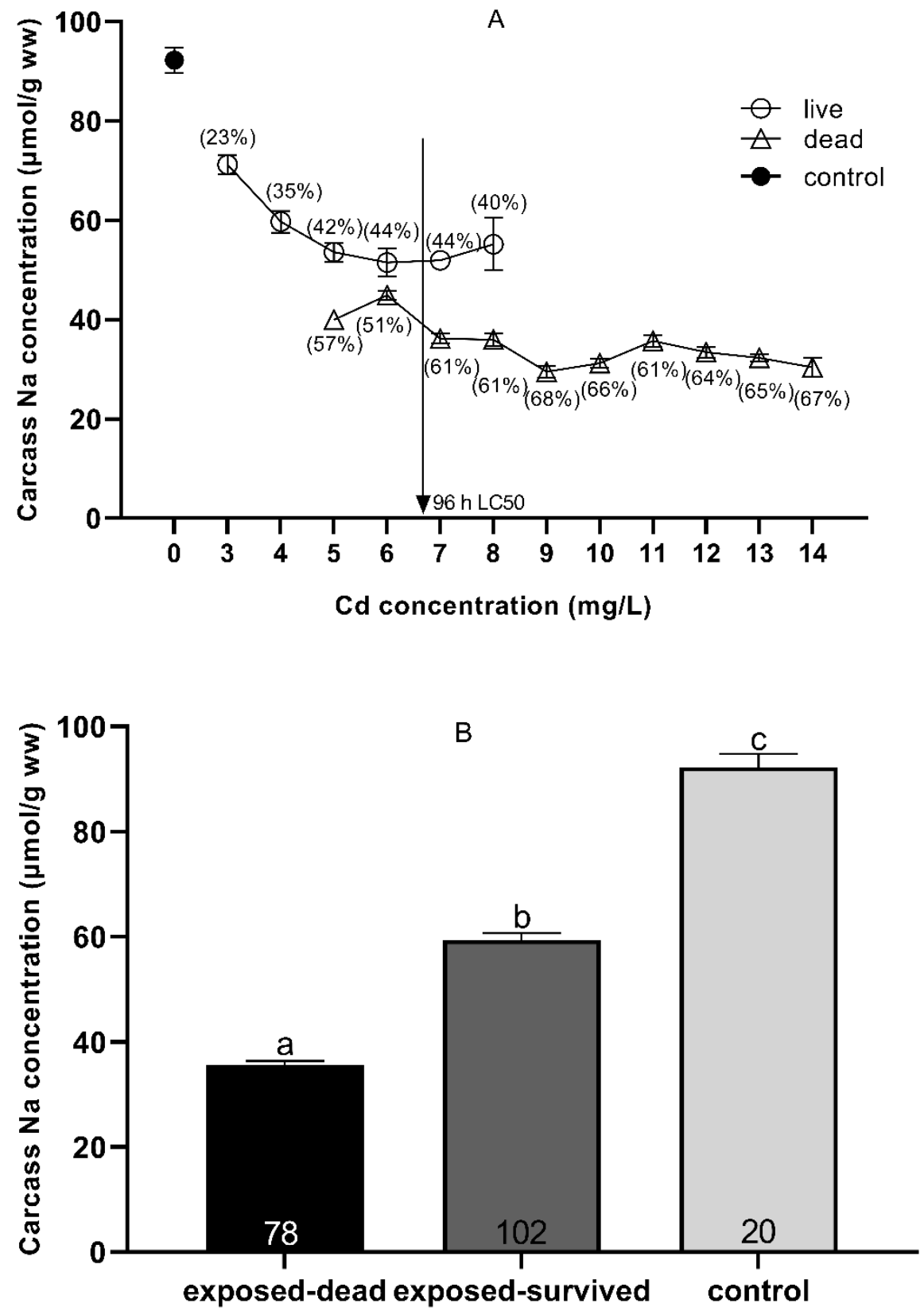

Figure 4. Carcass $\mathrm{Na}^{+}$(means $\pm \mathrm{SEM}$ ) in Silurus meridionalis sampled at death due to Cd exposure (A). The squares, circles, and triangles represent $\mathrm{Na}^{+}$levels in the control, live, and dead fish, respectively. The percentages represent carcass $\mathrm{Na}^{+}$losses in live and dead fish relative to the control fish. The vertical arrow shows the respective $96 \mathrm{~h} \mathrm{LC}_{50}$. In some cases, SEMs cannot be seen as they are smaller than the symbol used to indicate the mean. Carcass $\mathrm{Na}^{+}$concentration in the control, exposed-surviving, and exposed-dead fish across all treatments (B). Data are given as the mean \pm SEM. Sample size, n, was 20, 102, and 78 for the control, dead, and live fish, respectively. Means with different superscript letters $a, b, c$ differ significantly $(p<0.05)$. 

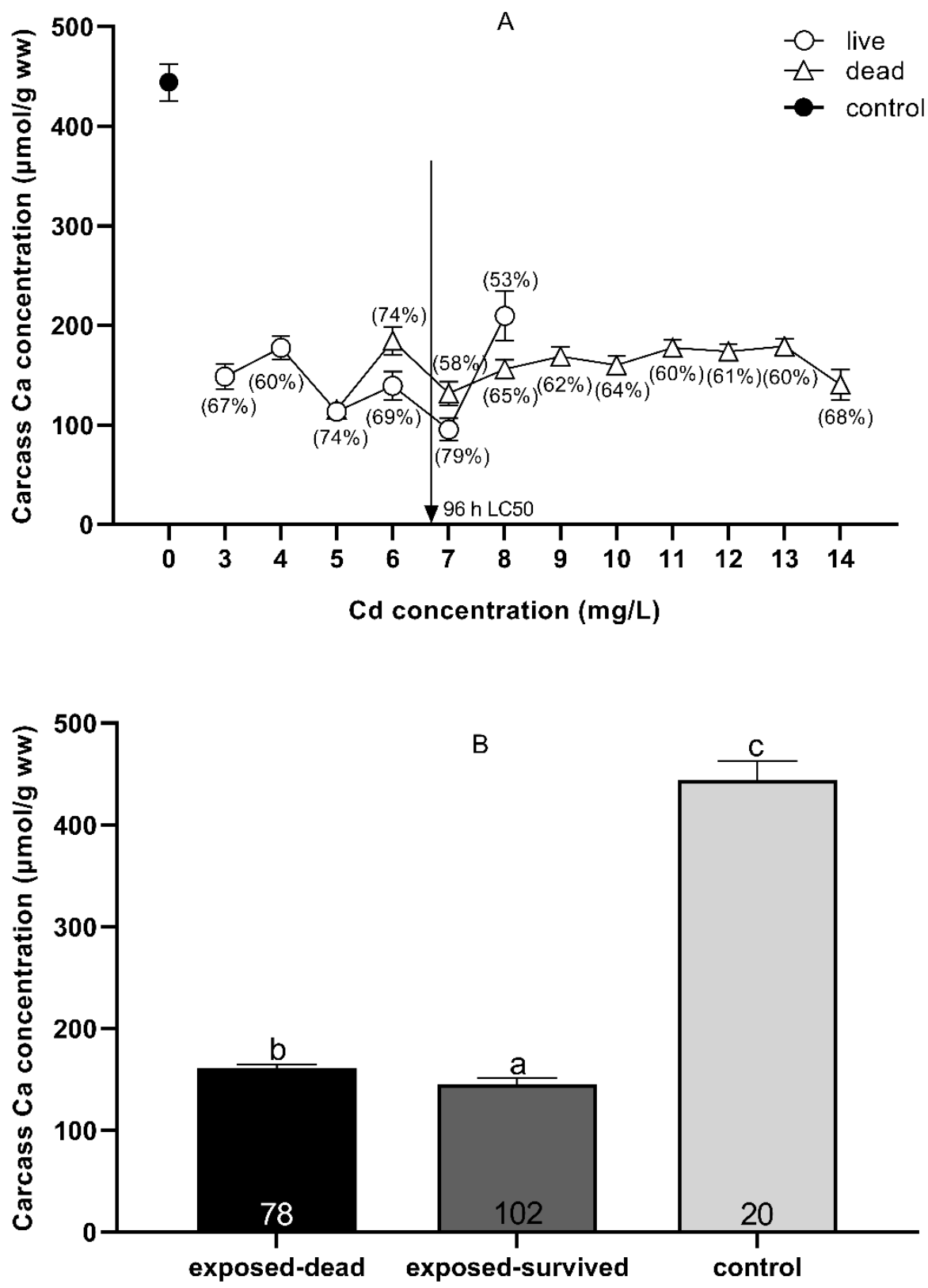

Figure 5. Carcass $\mathrm{Ca}^{2+}$ (means $\pm \mathrm{SEM}$ ) in Silurus meridionalis sampled at death due to Cd exposure (A). The squares, circles, and triangles represent $\mathrm{Ca}^{2+}$ levels in the control, live, and dead fish, respectively. The percentages represent carcass $\mathrm{Ca}^{2+}$ loss in live and dead fish relative to the control fish. The vertical arrow shows the respective $96 \mathrm{~h} \mathrm{LC}_{50}$. In some cases where SEMs cannot be seen, they are smaller than the symbol used to indicate the mean. The carcass $\mathrm{Ca}^{2+}$ concentration in the control, exposed-surviving, and exposed-dead fish across all treatments (B). Data are given as the mean \pm SEM. Sample size, n, was 20, 102, and 78 for the control, dead, and live fish, respectively. Means with different superscript letters $a, b, c$ differ significantly $(p<0.05)$.

\section{Discussion}

The $\mathrm{Cd}$ content and accumulation rate of different organs and the whole fish of southern catfish increased with the increase of the $\mathrm{Cd}$ exposure concentration, but there were obvious differences between dead and surviving individuals. The results showed that under the same $\mathrm{Cd}$ exposure concentration, the $\mathrm{Cd}$ content in the gills, kidneys, heart, carcass, and whole fish of southern catfish that died during the exposure was significantly higher than that of the surviving individuals, which was consistent with the higher $\mathrm{Cd}$ accumulation rate in the dead individuals. Toxic effects occur when the rate of 
accumulation of heavy metals exceeds the combined rate of detoxification and excretion of heavy metals [57]. The results of our study suggest that the accumulation rate of $\mathrm{Cd}$ is related to lethal toxicity.

The liver Cd content of dead southern catfish firstly increased with the increase of the $\mathrm{Cd}$ exposure concentration and then tended to be stable, staying within a small range of change (the mean value was $19.79 \mu \mathrm{g} / \mathrm{g}$ wet weight, about $99 \mu \mathrm{g} / \mathrm{g}$ dry weight, and liver water content was $80 \%$ ). This suggests that the accumulation of $\mathrm{Cd}$ in the liver reached saturation. Studies have shown that the liver tissue of carp (Cyprinus carpio) has a limited accumulation capacity for $\mathrm{Cd}$ and reaches saturation when the accumulation concentration of $\mathrm{Cd}$ reaches $90 \mu \mathrm{g} / \mathrm{g}$ dry weight [58]. This value is almost the same as the $\mathrm{Cd}$ accumulation saturation concentration in the livers of southern catfish in the current study. Generally, the liver is thought to be the first site of Cd storage; it not only acts as a storage organ but also as the primary site for the detoxification mechanisms of $\mathrm{Cd}$ [59]. The accumulation concentration of $\mathrm{Cd}$ in the liver reached saturation, reflecting the limited detoxification ability of the fish liver to respond to $\mathrm{Cd}$. $\mathrm{Cd}$ may be bound to metallothioneins in the liver, then transported to the kidneys, which are the main storage site for $\mathrm{Cd}$ [60]. The amount of $\mathrm{Cd}$ in the kidneys also reached saturation [58]. Although the accumulation concentration of $\mathrm{Cd}$ was highest in the kidneys of the dead fish in the current study, it did not reach saturation level. Thus, it can be supposed that after the $\mathrm{Cd}$ accumulation concentration in the livers of southern catfish reached saturation, there was a relative increase in $\mathrm{Cd}$ transport from the liver to the kidneys, and an increase in direct $\mathrm{Cd}$ intake into the kidneys from the blood. Moreover, the high $\mathrm{Cd}$ exposure concentration in our study might have caused the accumulation of $\mathrm{Cd}$ in the liver to reach saturation.

There was no overlap of whole-fish $\mathrm{Cd}$ accumulation concentrations for the southern catfish in the dead and surviving individuals; instead, there was a clear threshold (Figure 2), suggesting that there is a lethal threshold concentration for $\mathrm{Cd}$ accumulation in whole fish $(1.38 \mu \mathrm{g} / \mathrm{g}$ wet weight). The lethal threshold for $\mathrm{Cd}$ exposure in fish was only found for the $\mathrm{Cd}$ concentration in the gills [61] and in whole fish [62]. Previous studies on Cd toxicity of 31 different species of fish have shown that the whole-fish $\mathrm{Cd}$ concentration, which causes sublethal and lethal toxicity responses, occurs between 0.1 and $4 \mu \mathrm{g} / \mathrm{g}$ wet weight [34]. In our study, the lethal threshold of $\mathrm{Cd}$ concentration in southern catfish was determined as $1.38 \mu \mathrm{g} / \mathrm{g}$ wet weight, which is within the range of $\mathrm{Cd}$ concentrations indicated in the above-mentioned study. The threshold concentration obtained in this study for lethal toxicity due to acute $\mathrm{Cd}$ exposure of southern catfish may have important ecological and toxicological significance for environmental monitoring of the $\mathrm{Cd}$ concentration in fish [63]. No lethal threshold of $\mathrm{Cd}$ concentration was found in the tissues of the fish in the current study. After exposure to Cd, metallothionein (MT) expression is induced in the gills, liver, and kidneys, which binds with Cd in detoxification [64]. A toxicity effect occurs when the concentration of free heavy metal $\mathrm{Cd}$ ions exceeds the binding capacity of metallothionein [65]. Since only modest changes in whole fish concentrations of MT occur with exposure to metals, whole-fish $\mathrm{Cd}$ concentrations are preferred for assessing potentially toxic concentrations of $\mathrm{Cd}$ in fish [34]. The results of this study also support the view that the whole-fish $\mathrm{Cd}$ concentration is a more suitable surrogate for the effective concentration of toxicity [27].

The bioconcentration factor (BCF) was used to estimate the capacity of the fish to accumulate an element in its tissues $[56,66]$. The higher BCF values observed for the gill, liver, and kidney tissues reflected their high capacities for the accumulation of $\mathrm{Cd}$ present in a contaminated environment. Unlike other studies, our observations indicate that the BCF for $\mathrm{Cd}$ do not decrease with increasing exposure [66,67], except for BCF in the liver of dead fish. All BCF calculated in the study of Channa punctatzcs acute Cd poisoning [68] indicate that $\mathrm{BCF}$ in the gill, liver, and kidney tissues do not decrease with increasing exposure. A possible explanation for this difference is that they considered experimental exposure data to be acceptable only when the exposure duration was at least $28 \mathrm{~d}$ for fish [66], whereas in our study, the exposure concentrations were high and the exposure duration was short. 
Although BCF are often used to assess hazard risks, this method has received scrutiny for its application as a metric for metals $[15,66,69,70]$. To be a representative property of a contaminant, the BCF should be constant across different exposure conditions and species [15]. BCF in carcass and whole fish in the current study tended to be stable as the slopes neared zero, which indicate that these BCF can be useful in acute exposure conditions. All BCF calculated in this study are higher than channel catfish (Ictalurus punctatus) chronic exposure to environmental Cd [69].

The results show that acute $\mathrm{Cd}$ exposure led to the loss of $\mathrm{Ca}$ and $\mathrm{Na}$ ions in the southern catfish, and that the rate of $\mathrm{Na}$ ion loss in the carcass of dead fish was significantly higher than that in the surviving fish (Figure 4), which indicates that the lethal toxicity of acute $\mathrm{Cd}$ exposure is related to the loss of $\mathrm{Na}$ ions. A large number of studies have shown that exposure to $\mathrm{Cd}$ inhibits carbonic anhydrase and $\mathrm{Na}^{+} / \mathrm{K}^{+}$-ATPase activity in the gills and kidneys $[39,44,46]$ and induces endocrine stress responses [14,41], leading to a loss of $\mathrm{Na}$ ions in fish that kills the fish by causing the cardiovascular system collapse [71,72]. The consistency of the whole-body $\mathrm{Na}^{+}$content of dead fish across all exposure concentrations (Figure 4) suggests that there is a critical $\mathrm{Na}^{+}$level, circa $34.54 \mu \mathrm{mol} / \mathrm{g}$ wet weight, below which survival is no longer possible. Our findings provide new evidence supporting the research of Veltman et al. (2014), who concluded that when the Na ion concentration in the body of freshwater aquatic organisms is below a certain threshold, it leads to death [42]. Our results are also consistent with the conclusion that the significance of the exposure of zebrafish (Danio rerio) to $\mathrm{Cd}$ is related to a threshold of $\mathrm{Na}$ ion concentration [73].

The acute toxicity mechanism resulting from exposure of fish to $\mathrm{Cd}$ is the disruption of $\mathrm{Ca}$ ion homeostasis $[36,45]$. Water $\mathrm{Cd}^{2+}$ and $\mathrm{Ca}^{2+}$ compete for apical $\mathrm{Ca}^{2+}$ channels in the gill tissue [74], $\mathrm{Cd}^{2+}$ inhibits basolateral $\mathrm{Ca}^{2+}$-ATPase activity in the gills [75], and $\mathrm{Cd}^{2+}$ inhibits $\mathrm{Ca}^{2+}$-ATPase activity in the muscles [76]. Although exposure to $\mathrm{Cd}$ resulted in a decrease in the concentration of $\mathrm{Ca}$ ions in the southern catfish, the overall mean value of $\mathrm{Ca}$ ion concentration in the carcasses of dead fish was higher than the $\mathrm{Ca}$ ion concentration in the carcasses of surviving fish (Figure 5), indicating that the decreased $\mathrm{Ca}$ ion concentration in the carcass was not correlated with the death of the southern catfish resulting from acute $\mathrm{Cd}$ exposure. In addition, we should also note that at very high waterborne $\mathrm{Cd}$ concentrations at a lethal concentration, high concentrations of metals may accumulate on the respiratory surface and prevent the respiratory gas exchange, thus leading to suffocation [28].

\section{Conclusions}

In conclusion, the $\mathrm{Cd}$ content and accumulation rate in different organs and the whole fish of the southern catfish were positively correlated with Cd exposure concentration, and there were obvious differences between dead and surviving individuals. The quantitative relationships between $\mathrm{Cd}$ accumulation concentration in different tissues of fish and $\mathrm{Cd}$ exposure concentrations was provided in the current study under acute exposure conditions. These results indicated that both the $\mathrm{Cd}$ content of tissues and $\mathrm{Cd}$ accumulation rates were correlated with mortality. The $\mathrm{Cd}$ content of the liver of dead fish reached saturation $(19.79 \mu \mathrm{g} / \mathrm{g}$ wet weight), and the Cd content of the kidneys increased with the increase in $\mathrm{Cd}$ exposure concentration, indicating that the detoxification ability of the liver of southern catfish was limited. There is a lethal threshold concentration $(1.38 \mu \mathrm{g} / \mathrm{g}$ wet weight) for the accumulation of $\mathrm{Cd}$ in whole fish, which can be used as an indicator of environmental toxicology. Unlike other studies, our observations indicate that the $\mathrm{BCF}$ for $\mathrm{Cd}$ do not decrease with increasing exposure. The lethal toxicity to southern catfish resulting from acute $\mathrm{Cd}$ exposure is related to a decrease in the $\mathrm{Na}$ ion concentration, while decreased $\mathrm{Ca}$ ion concentrations in the carcass are not correlated with acute exposure to $\mathrm{Cd}$ that lead to the death of the southern catfish. The present work provides preliminary insights into the possible impacts of sudden high levels of $\mathrm{Cd}$ contaminants in freshwater ecosystem. The results suggest that whole-fish $\mathrm{Cd}$ content and carcass $\mathrm{Na}^{+}$content are useful indicators of fish acutely exposed to $\mathrm{Cd}$. 
Fish can uptake waterborne and foodborne $\mathrm{Cd}$. Fish have high affinity to $\mathrm{Cd}$. Metals are not degradable but rather accumulate in the environment, and due to the biomagnification effect, they move up the food chain, progressively increasing their concentrations in the tissues of fish [7]. This can be a public health concern. In the future, it will be necessary to investigate $\mathrm{Cd}$ accumulation and effects when the southern catfish are exposed through environmentally relevant $\mathrm{Cd}$ and food.

Author Contributions: Conceptualization, W.L. and X.X.; funding acquisition, Y.Y. and W.L.; exposure methodology, W.L. and H.Q.; cadmium and electrolyte analysis methodology, W.L.; writingoriginal draft preparation, W.L.; writing—review and editing, W.L. and X.X. All authors have read and agreed to the published version of the manuscript.

Funding: This research was funded by the Natural Science Foundation of China (No.31300338) and the Fundamental Research Funds for the Central Universities (No. XDJK2016C113; XDJK2016C125; XDJK2016C156).

Institutional Review Board Statement: This study was performed ethically and in accordance with the Institutional Animal Care and Use Committee (IACUC) guidelines of Southwest University (IACUC-20180303-01, 3 March 2018).

Informed Consent Statement: Not applicable.

Data Availability Statement: Not applicable.

Acknowledgments: We thank Daofu Ming, Jingjing Zhang, Fenglei Zhu, Jing Long, and Yiguo Xia for their experimental assistance. We sincerely thank the anonymous reviewers for their helpful suggestions and comments. We also thank MDPI for English editing services.

Conflicts of Interest: The authors declare no conflict of interest.

\section{Appendix A}

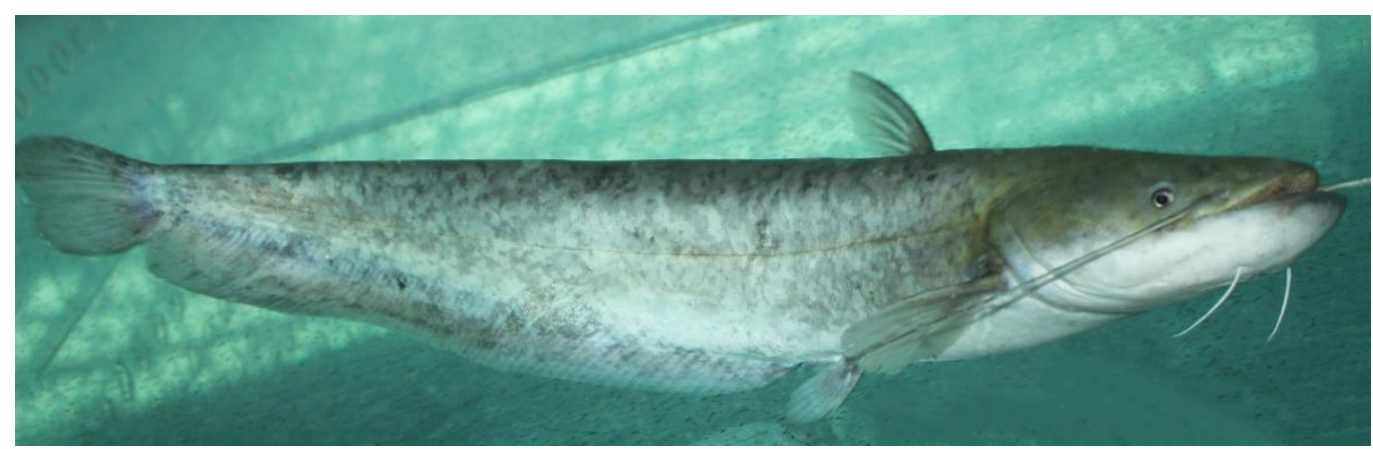

Figure A1. A picture of the southern catfish (Silurus meridionalis Chen). 

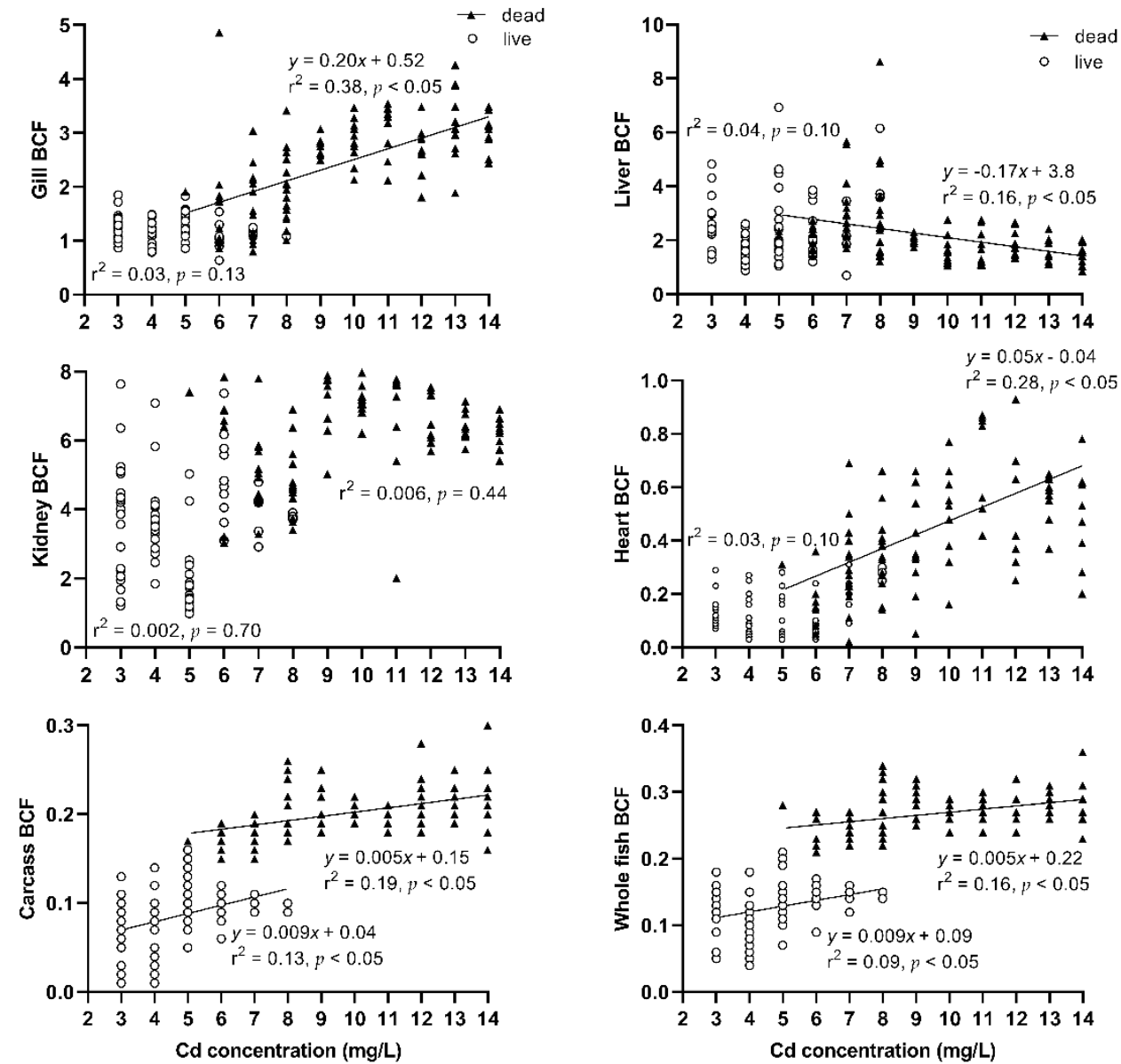

Figure A2. Relationship between exposure concentration and the BCF of gills, liver, kidneys, heart, carcass, and whole fish of Silurus meridionalis. Triangles represent fish that died within $96 \mathrm{~h}$, and circles represent fish that survived the $96 \mathrm{~h}$ exposure.

\section{References}

1. Sokolova, I.M.; Lannig, G. Interactive effects of metal pollution and temperature on metabolism in aquatic ectotherms: Implications of global climate change. Clim. Res. 2008, 37, 181-201. [CrossRef]

2. Fazio, F.; Piccione, G.; Tribulato, K.; Ferrantelli, V.; Giangrosso, G.; Arfuso, F.; Faggio, C. Bioaccumulation of heavy metals in blood and tissue of striped mullet in two Italian lakes. J. Aquat. Anim. Health 2014, 26, 278-284. [CrossRef] [PubMed]

3. Renieri, E.; Alegakis, A.; Kiriakakis, M.; Vinceti, M.; Ozcagli, E.; Wilks, M.; Tsatsakis, A. Cd, Pb and Hg Biomonitoring in Fish of the Mediterranean Region and Risk Estimations on Fish Consumption. Toxics 2014, 2, 417-442. [CrossRef]

4. McGeer, J.C.; Szebedinszky, C.; Gordon McDonald, D.; Wood, C.M. Effects of chronic sublethal exposure to waterborne Cu, Cd or $\mathrm{Zn}$ in rainbow trout 2: Tissue specific metal accumulation. Aquat. Toxicol. 2000, 50, 245-256. [CrossRef]

5. De Silva, N.A.L.; Marsden, I.D.; Gaw, S.; Glover, C.N. Acute waterborne cadmium toxicity in the estuarine pulmonate mud snail, Amphibola crenata. Ecotoxicol. Environ. Saf. 2018, 158, 274-283. [CrossRef]

6. Shekh, K.; Tang, S.; Kodzhahinchev, V.; Niyogi, S.; Hecker, M. Species and life-stage specific differences in cadmium accumulation and cadmium induced oxidative stress, metallothionein and heat shock protein responses in white sturgeon and rainbow trout. Sci. Total Environ. 2019, 673, 318-326. [CrossRef] [PubMed]

7. Deidda, I.; Russo, R.; Bonaventura, R.; Costa, C.; Zito, F.; Lampiasi, N. Neurotoxicity in Marine Invertebrates: An Update. Biology 2021, 10, 161. [CrossRef] [PubMed]

8. Sonone, S.S.; Jadhav, S.; Sankhla, M.S.; Kumar, R. Water Contamination by Heavy Metals and their Toxic Effect on Aquaculture and Human Health through Food Chain. Lett. Appl. NanoBioScience 2020, 10, 2148-2166. [CrossRef]

9. Guo, S.; Zheng, J.; Yuan, S.; Zhu, Q. Effects of heat and cadmium exposure on stress-related responses in the liver of female zebrafish: Heat increases cadmium toxicity. Sci. Total Environ. 2018, 618, 1363-1370. [CrossRef]

10. Yang, J.; Liu, D.; He, Y.; Wang, L. Mitochondrial energy metabolism in the hepatopancreas of freshwater crabs (Sinopotamon henanense) after cadmium exposure. Environ. Sci. Process Impacts 2014, 17, 156-165. [CrossRef] [PubMed]

11. Zhou, L.B.; Wu, Q.; Gao, G.L. Remediation of Lead-Zinc Contaminated Soil in China. Appl. Mech. Mater. 2012, 209-211, 1116-1119. [CrossRef] 
12. Bervoets, L.; Van Campenhout, K.; Reynders, H.; Knapen, D.; Covaci, A.; Blust, R. Bioaccumulation of micropollutants and biomarker responses in caged carp (Cyprinus carpio). Ecotoxicol. Environ. Saf. 2009, 72, 720-728. [CrossRef] [PubMed]

13. Abdel-Tawwab, M.; Wafeek, M. Fluctuations in water temperature affected waterborne cadmium toxicity: Hematology, anaerobic glucose pathway, and oxidative stress status of Nile tilapia, Oreochromis niloticus (L.). Aquaculture 2017, 477, 106-111. [CrossRef]

14. Alsop, D.; Wood, C.M. Metal uptake and acute toxicity in zebrafish: Common mechanisms across multiple metals. Aquat. Toxicol. 2011, 105, 385-393. [CrossRef] [PubMed]

15. McGeer, J.C.; Niyogi, S.; Smith, D.S. Cadmium. In Fish Physiology; Wood, C.M., Farrell, A.P., Brauner, C.J., Eds.; Elsevier: Amsterdam, The Netherlands, 2011; Volume 31B, pp. 125-184.

16. Arini, A.; Gourves, P.Y.; Gonzalez, P.; Baudrimont, M. Metal detoxification and gene expression regulation after a Cd and Zn contamination: An experimental study on Danio rerio. Chemosphere 2015, 128, 125-133. [CrossRef]

17. Kakade, A.; Salama, E.; Pengya, F.; Liu, P.; Li, X. Long-term exposure of high concentration heavy metals induced toxicity, fatality, and gut microbial dysbiosis in common carp, Cyprinus carpio. Environ. Pollut. 2020, 266, 115293. [CrossRef]

18. Acosta, I.B.; Junior, A.S.V.; Silva, E.F.E.; Cardoso, T.F.; Caldas, J.S.; Jardim, R.D.; Corcini, C.D. Effects of exposure to cadmium in sperm cells of zebrafish, Danio rerio. Toxicol. Rep. 2016, 3, 696-700. [CrossRef]

19. Renieri, E.A.; Sfakianakis, D.G.; Alegakis, A.A.; Safenkova, I.V.; Buha, A.; Matović, V.; Tzardi, M.; Dzantiev, B.B.; Divanach, P.; Kentouri, M.; et al. Nonlinear responses to waterborne cadmium exposure in zebrafish. An in vivo study. Environ. Res. 2017, 157, 173-181. [CrossRef] [PubMed]

20. Irfan, M.; Liu, X.; Hussain, K.; Mushtaq, S.; Cabrera, J.; Zhang, P. The global research trend on cadmium in freshwater: A bibliometric review. Environ. Sci. Pollut. Res. 2021. Online ahead of print. [CrossRef]

21. Sprague, J.B. Measurement of pollutant toxicity to fish I. bioassay methods for acute toxicity. Water Res. 1969, 3, 793-821. [CrossRef]

22. Redeker, E.S.; Blust, R. Accumulation and Toxicity of Cadmium in the Aquatic Oligochaete Tubifex tubifex: A Kinetic Modeling Approach. Environ. Sci. Technol. 2004, 38, 537-543. [CrossRef]

23. Tsui, M.T.K.; Wang, W. Acute Toxicity of Mercury to Daphnia magna under Different Conditions. Environ. Sci. Technol. 2006, 40, 4025-4030. [CrossRef] [PubMed]

24. US EPA. Ecotox Database. Available online: https://cfpub.epa.gov/ecotox/index.cfm (accessed on 12 October 2020).

25. Vergauwen, L.; Knapen, D.; Hagenaars, A.; Blust, R. Hypothermal and hyperthermal acclimation differentially modulate cadmium accumulation and toxicity in the zebrafish. Chemosphere 2013, 91, 521-529. [CrossRef]

26. Wang, J.; Zhang, H.; Zhang, T.; Zhang, R.; Liu, R.; Chen, Y. Molecular mechanism on cadmium-induced activity changes of catalase and superoxide dismutase. Int. J. Biol. Macromol. 2015, 77, 59-67. [CrossRef]

27. Meador, J.P.; McCarty, L.S.; Escher, B.I.; Adams, W.J. 10th Anniversary Critical Review: The tissue-residue approach for toxicity assessment: Concepts, issues, application, and recommendations. J. Environ. Monit. 2008, 10, 1486-1498. [CrossRef] [PubMed]

28. Adams, W.J.; Blust, R.; Borgmann, U.; Brix, K.V.; DeForest, D.K.; Green, A.S.; Meyer, J.S.; McGeer, J.C.; Paquin, P.R.; Rainbow, P.S.; et al. Utility of tissue residues for predicting effects of metals on aquatic organisms. Integr. Environ. Assess. Manag. 2011, 7, 75-98. [CrossRef]

29. Meador, J.P.; Adams, W.J.; Escher, B.I.; McCarty, L.S.; McElroy, A.E.; Sappington, K.G. The tissue residue approach for toxicity assessment: Findings and critical reviews from a Society of Environmental Toxicology and Chemistry Pellston Workshop. Integr. Environ. Assess. Manag. 2011, 7,310. [CrossRef]

30. Leonard, E.M.; Marentette, J.R.; Balshine, S.; Wood, C.M. Critical body residues, Michaelis-Menten analysis of bioaccumulation, lethality and behaviour as endpoints of waterborne Ni toxicity in two teleosts. Ecotoxicology 2014, 23, 147-162. [CrossRef]

31. Wang, W.; Tan, Q. Applications of dynamic models in predicting the bioaccumulation, transport and toxicity of trace metals in aquatic organisms. Environ. Pollut. 2019, 252, 1561-1573. [CrossRef] [PubMed]

32. Penttinen, S.; Malk, V.; Väisänen, A.; Penttinen, O.P. Using the critical body residue approach to determine the acute toxicity of cadmium at varying levels of water hardness and dissolved organic carbon concentrations. Ecotoxicol. Environ. Saf. 2011, 74, 1151-1155. [CrossRef] [PubMed]

33. Méndez-Fernández, L.; Martínez-Madrid, M.; Rodriguez, P. Toxicity and critical body residues of Cd, Cu and Cr in the aquatic oligochaete Tubifex tubifex (Müller) based on lethal and sublethal effects. Ecotoxicology 2013, 22, 1445-1460. [CrossRef]

34. Meador, J.P. Tissue concentrations as the dose metric to assess potential toxic effects of metals in field-collected fish: Copper and cadmium. Environ. Toxicol. Chem. 2015, 34, 1309-1319. [CrossRef]

35. Delahaut, V.; Rašković, B.; Salvado, M.S.; Bervoets, L.; Blust, R.; De Boeck, G. Toxicity and bioaccumulation of Cadmium, Copper and Zinc in a direct comparison at equitoxic concentrations in common carp (Cyprinus carpio) juveniles. PLoS ONE 2020, 15, e220485. [CrossRef]

36. Pilehvar, A.; Town, R.M.; Blust, R. The effect of thermal pre-incubation and exposure on sensitivity of zebrafish (Danio rerio) to copper and cadmium single and binary exposures. Aquat. Toxicol. 2019, 213, 105226. [CrossRef] [PubMed]

37. Roch, M.; Maly, E.J. Relationship of Cadmium-Induced Hypocalcemia with Mortality in Rainbow Trout (Salmo gairdneri) and the Influence of Temperature on Toxicity. J. Fish. Res. Board Can. 1979, 36, 1297-1303. [CrossRef]

38. Suresh, A.; Sivaramakrishna, B.; Radhakrishnaiah, K. Effect of lethal and sublethal concentrations of cadmium on energetics in the gills of fry and fingerlings of Cyprinus-carpio. Bull. Environ. Contam. Toxicol. 1993, 51, 920-926. [CrossRef] [PubMed] 
39. McGeer, J.C.; Szebedinszky, C.; McDonald, D.G.; Wood, C.M. Effects of chronic sublethal exposure to waterborne Cu, Cd or Zn in rainbow trout. 1: Iono-regulatory disturbance and metabolic costs. Aquat. Toxicol. 2000, 50, 231-243. [CrossRef]

40. Rogers, J.T.; Richards, J.G.; Wood, C.M. Ionoregulatory disruption as the acute toxic mechanism for lead in the rainbow trout (Oncorhynchus mykiss). Aquat. Toxicol. 2003, 64, 215-234. [CrossRef]

41. Alsop, D.; Wood, C.M. Metal and pharmaceutical mixtures: Is ion loss the mechanism underlying acute toxicity and widespread additive toxicity in zebrafish? Aquat. Toxicol. 2013, 140-141, 257-267. [CrossRef]

42. Veltman, K.; Hendriks, A.J.; Huijbregts, M.A.J.; Wannaz, C.; Jolliet, O. Toxicokinetic Toxicodynamic (TKTD) Modeling of Ag Toxicity in Freshwater Organisms: Whole-Body Sodium Loss Predicts Acute Mortality Across Aquatic Species. Environ. Sci. Technol. 2014, 48, 14481-14489. [CrossRef]

43. Castaldo, G.; Pillet, M.; Slootmaekers, B.; Bervoets, L.; Town, R.M.; Blust, R.; De Boeck, G. Investigating the effects of a sub-lethal metal mixture of $\mathrm{Cu}, \mathrm{Zn}$ and $\mathrm{Cd}$ on bioaccumulation and ionoregulation in common carp, Cyprinus carpio. Aquat. Toxicol. 2020, 218, 105363. [CrossRef]

44. Silva, A.O.F.D.; Martinez, C.B.R. Acute effects of cadmium on osmoregulation of the freshwater teleost Prochilodus lineatus: Enzymes activity and plasma ions. Aquat. Toxicol. 2014, 156, 161-168. [CrossRef]

45. Shekh, K.; Tang, S.; Hecker, M.; Niyogi, S. Investigating the Role of Ionoregulatory Processes in the Species- and Life-Stage-Specific Differences in Sensitivity of Rainbow Trout and White Sturgeon to Cadmium. Environ. Sci. Technol. 2018, 52, 12868-12876. [CrossRef]

46. McRae, N.K.; Gaw, S.; Glover, C.N. Effects of waterborne cadmium on metabolic rate, oxidative stress, and ion regulation in the freshwater fish, inanga (Galaxias maculatus). Aquat. Toxicol. 2018, 194, 1-9. [CrossRef]

47. Xie, X.; Sun, R. The bioenergetics of the southern catfish (Silurus meridionah Chen): Growth rate as a function of ration level, body weight, and temperature. J. Fish. Biol. 1992, 40,719-730. [CrossRef]

48. Zhang, Z.; Xu, W.; Tang, R.; Li, L.; Refaey, M.M.; Li, D. Thermally processed diet greatly affects profiles of amino acids rather than fatty acids in the muscle of carnivorous Silurus meridionalis. Food Chem. 2018, 256, 244-251. [CrossRef]

49. Wang, L.; Wang, H. Status and Strategy for Protection of Fishes in Changjiang River. J. Anhui Agric. Sci. $2011,39,12876-12877$.

50. Javed, M.; Abbas, S.; Latif, F. Bioaccumulation of Metals in Fish, Channa marulius, Mystus seenghala and Wallago attu during Acute Toxicity Exposures. Int. J. Agric. Biol. 2017, 19, 1566-1570. [CrossRef]

51. Li, J.; Xie, X. Inconsistent responses of liver mitochondria metabolism and standard metabolism in Silurus meridionalis when exposed to waterborne cadmium. Comp. Biochem. Physiol. Part C Toxicol. Pharmacol. 2018, 214, 17-22. [CrossRef]

52. Li, J.; Yan, Y.; Xie, X. Tissue-Specific Antioxidative Responses and Cadmium Accumulation in Silurus meridionalis Under Chronic Waterborne Cadmium Exposure. Bull. Environ. Contam. Toxicol. 2018, 100, 485-491. [CrossRef]

53. Li, J.; Xie, X. Effects of waterborne cadmium exposure on growth performance, specific dynamic action, and energy budget of southern catfish Silurus meridionalis. Aquaculture 2019, 511, 634194. [CrossRef]

54. Chowdhury, M.J.; Baldisserotto, B.; Wood, C.M. Tissue-Specific Cadmium and Metallothionein Levels in Rainbow Trout Chronically Acclimated to Waterborne or Dietary Cadmium. Arch. Environ. Con. Toxicol. 2005, 48, 381-390. [CrossRef] [PubMed]

55. Yılmaz, M.; Gül, A.; Karaköse, E. Investigation of acute toxicity and the effect of cadmium chloride $\left(\mathrm{CdCl}_{2} \cdot \mathrm{H}_{2} \mathrm{O}\right) \mathrm{metal}$ salt on behavior of the guppy (Poecilia reticulata). Chemosphere 2004, 56, 375-380. [CrossRef] [PubMed]

56. Ferreira, N.S.; Oliveira, L.H.B.; Agrelli, V.; de Oliveira, A.F.; Nogueira, A.R.A.; Oliveira, A.; Gonzalez, M.H. Bioaccumulation and acute toxicity of $\mathrm{As}(\mathrm{III})$ and $\mathrm{As}(\mathrm{V})$ in Nile tilapia (Oreochromis niloticus). Chemosphere 2019, 217, 349-354. [CrossRef]

57. Rainbow, P.S. Trace metal bioaccumulation: Models, metabolic availability and toxicity. Environ. Int. 2007, 33, 576-582. [CrossRef] [PubMed]

58. de Conto Cinier, C.; Faure, R.; Garin, D. Cadmium bioaccumulation in carp (Cyprinus carpio) tissues during long-term high exposure: Analysis by inductively coupled plasma-mass spectrometry. Ecotoxicol. Environ. Saf. 1997, 38, 137-143. [CrossRef]

59. Olsson, P.E.; Larsson, A.; Maage, S.; Haux, C.; Bonham, K.; Zafarullah, M.; Gedamu, L. Induction of metallothionein synthesis in rainbow trout, Salmo gairdneri, during long-term exposure to water borne cadmium. Fish Physiol. Biochem. 1989, 6, $221-229$. [CrossRef] [PubMed]

60. Gill, T.S.; Bianchi, C.P.; Epple, A. Trace metal ( $\mathrm{Cu}$ and $\mathrm{Zn})$ adaptation of organ systems of the American eel, Anguilla rostrata, to external concentrations of cadmium. Comp. Biochem. Physiol. Part C Comp. Pharmacol. 1992, 102, 361-371. [CrossRef]

61. Mount, D.I.; Stephan, C.E. A method for detecting cadmium poisoning in fish. J. Wildl. Manag. 1967, 31, 168. [CrossRef]

62. Xie, L.; Klerks, P.L. Changes in cadmium accumulation as a mechanism for cadmium resistance in the least killifish Heterandria formosa. Aquat. Toxicol. 2004, 66, 73-81. [CrossRef]

63. Niimi, A.J.; Kissoon, G.P. Evaluation of the critical body burden concept based on inorganic and organic mercury toxicity to Rainbow Trout (Oncorhynchus mykiss). Arch. Environ. Contam. Toxicol. 1994, 26, 169-178. [CrossRef]

64. Hollis, L.; Hogstrand, C.; Wood, C.M. Tissue-Specific Cadmium Accumulation, Metallothionein Induction, and Tissue Zinc and Copper Levels During Chronic Sublethal Cadmium Exposure in Juvenile Rainbow Trout. Arch. Environ. Contam. Toxicol. 2001, 41, 468-474. [CrossRef]

65. Vijver, M.G.; van Gestel, C.A.M.; Lanno, R.P.; van Straalen, N.M.; Peijnenburg, W.J.G.M. Internal Metal Sequestration and Its Ecotoxicological Relevance: A Review. Environ. Sci. Technol. 2004, 38, 4705-4712. [CrossRef] [PubMed] 
66. McGeer, J.C.; Brix, K.V.; Skeaff, J.M.; DeForest, D.K.; Brigham, S.I.; Adams, W.J.; Green, A. Inverse relationship between bioconcentration factor and exposure concentration for metals: Implications for hazard assessment of metals in the aquatic environment. Environ. Toxicol. Chem. 2003, 22, 1017-1037. [CrossRef] [PubMed]

67. DeForest, D.K.; Brix, K.V.; Adams, W.J. Assessing metal bioaccumulation in aquatic environments: The inverse relationship between bioaccumulation factors, trophic transfer factors and exposure concentration. Aquat. Toxicol. 2007, 84, 236-246. [CrossRef]

68. Gupta, A.K.; Rajbanshi, V.K. Acute Toxicity of Cadmium to Channa punctutus (Bloch). Acta Hydrochim. Hydrobiol. 1988, 5, 525-535. [CrossRef]

69. Paul, J.S.; Small, B.C. Chronic exposure to environmental cadmium affects growth and survival, cellular stress, and glucose metabolism in juvenile channel catfish (Ictalurus punctatus). Aquat. Toxicol. 2021, 230, 105705. [CrossRef] [PubMed]

70. Fairbrother, A.; Wenstel, R.; Sappington, K.; Wood, W. Framework for metals risk assessment. Ecotoxicol. Environ. Saf. 2007, 68, 145-227. [CrossRef]

71. Milligan, C.L.; Wood, C.M. Disturbances in hematology, fluid volume distribution, and circulatory function associated with low environmental $\mathrm{pH}$ in the rainbow trout, Salmo gairdneri. J. Exp. Biol. 1982, 99, 397-415. [CrossRef]

72. Wilson, R.; Taylor, E. The physiological responses of freshwater rainbow trout, Oncorhynchus mykiss, during acutely lethal copper exposure. J. Comp. Physiol. B 1993, 163, 38-47. [CrossRef]

73. Pilehvar, A.; Cordery, K.I.; Town, R.M.; Blust, R. The synergistic toxicity of Cd(II) and Cu(II) to zebrafish (Danio rerio): Effect of water hardness. Chemosphere 2020, 247, 125942. [CrossRef]

74. Playle, R.C.; Dixon, D.G. Copper and Cadmium Binding to Fish Gill: Estimates of metal-gill stability constants and modelling of metal accumulation. Can. J. Fish. Aqucrt. Sci. 1993, 50, 2678-2687. [CrossRef]

75. Verbost, P.M.; Flik, G.; Lock, R.A.C.; Wendelaar Bonga, S.E. Cadmium inhibits plasma membrane calcium transport. J. Membr. Biol. 1988, 102, 97-104. [CrossRef] [PubMed]

76. Suresh, A.; Sivaramakrishna, B.; Radhakrishnaiah, K. Cadmium induced changes in ion levels and ATPase activities in the muscle of the fry and fingerlings of the freshwater fish, Cyprinus carpio. Chemosphere 1995, 30, 367-375. [CrossRef] 